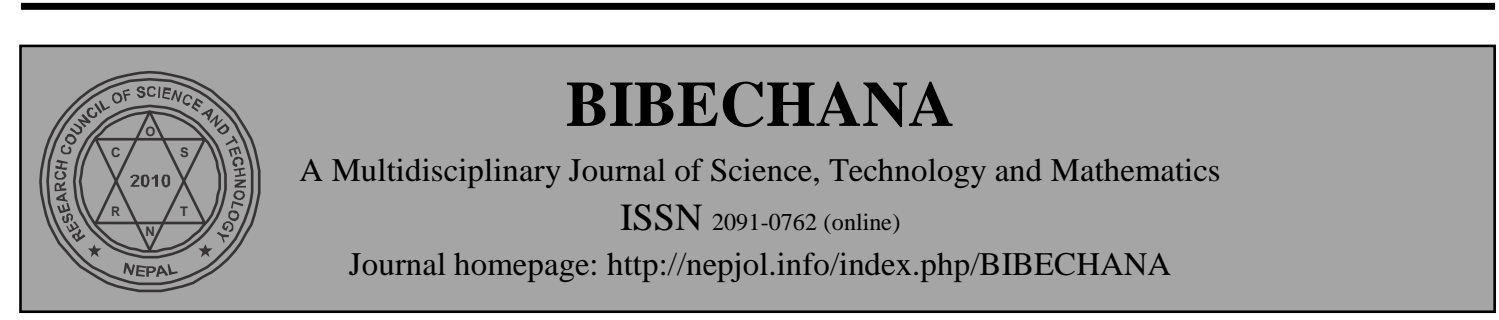

\title{
Description on some rescued turtles and their translocation at Turtle Rescue and Conservation Centre (TRCC), Sanischare, Jhapa
}

\author{
Milan Kharel $^{1 *}$ and Damodar Thapa Chhetry ${ }^{2}$ \\ ${ }^{1}$ Department of Zoology, Lord Buddha College, Biratnagar, Nepal \\ ${ }^{2}$ Department of Zoology, P.G. Campus, Tribhuvan University, Biratnagar, Nepal \\ *Corresponding author: E-mail: milankhare12000@yahoo.com
}

Accepted for publication: February 12, 2014

\begin{abstract}
The present paper deals with the brief introduction of Turtle Rescue and Conservation Centre (TRCC) and description of some rescued turtles. Nine specimens of turtles belonging to five genera were rescued and translocated to the centre till date including $9.3 \mathrm{~kg}$ male Indian Peacock soft-shelled turtle (Nilssonia hurum) for the first time from Jhapa district. The rescue operations were conducted for the translocation of turtles confiscated from the local market, censorial collectors, fisherman and public residence. The high resolution photographs of captured specimens, their necessary biometry and GPS coordinates of location were taken. Species identification was done with the help of and pictorial field guide and relevant literatures. Climatic data of study area were recorded from Gainde Irrigation Project, Maidhar, Jhapa. Interviews were taken during field visits with the help of structured questionnaire. Preliminary rescue data showed that the Indian flap-shelled turtle (Lissemys punctata) and Yellow bellied roofed turtle (Pangshura flaviventer) were the most overexploited species in the vicinities of the study area. The climatic condition of the rescue centre and water quality found suitable to support terrestrial and freshwater turtles and other various wetland flora and fauna. However, the rapid population growth and habitat destruction due to deforestation, unmanaged urbanization and expansion of agricultural land are found as the major threats to the survival of turtles and other wetland creatures at the study area and its vicinities.
\end{abstract}

(C) 2014 RCOST: All rights reserved.

Keywords: Nilssonia hurum; Lissemys punctata; Freshwater turtle; Budhoholi wetland; TRCC.

\section{Introduction}

Turtle Rescue and Conservation Centre (TRCC), is established for the first time in the Eastern Nepal having an ample motto of 'saving turtles for future generations'. The centre is located in the vicinity of wetland cum Sal dominated forest area formed by the old course of Aduwa River called Budho Holi or Bhimsen Pokhari, within the premises of Sukhani Martyr's Memorial Foundation (SUMMEF) at Sanischare-6, Salbari, Jhapa district in south-east Nepal. The area is about $0.235 \mathrm{sq} \mathrm{km} \mathrm{(22.4} \mathrm{ha)} \mathrm{and}$ geographically located between $88^{\circ} 00$ ' 59.04" E to $26^{\circ} 40^{\prime} 20.64^{\prime \prime} \mathrm{N}$ at an altitude of $145 \mathrm{~m}$ from msl [1]. The Centre has been established by the joint venture of Amphibians and reptiles conservation Nepal (ARCO-Nepal) and Sukhani Martyr's Memorial Foundation (SUMMEF) with the legal consent of government of Nepal under the ministry of physical planning and construction. It was inaugurated jointly on $15^{\text {th }}$ April 2012 by Prof. Dr. Hermann Schleich, Chair of ARCO-Nepal and Mr. Devraj Ghimire, President of SUMMEF on the auspicious presence of government authority, national and international delegates, subject experts distinguish scholars, locals and media persons. The first author is going 

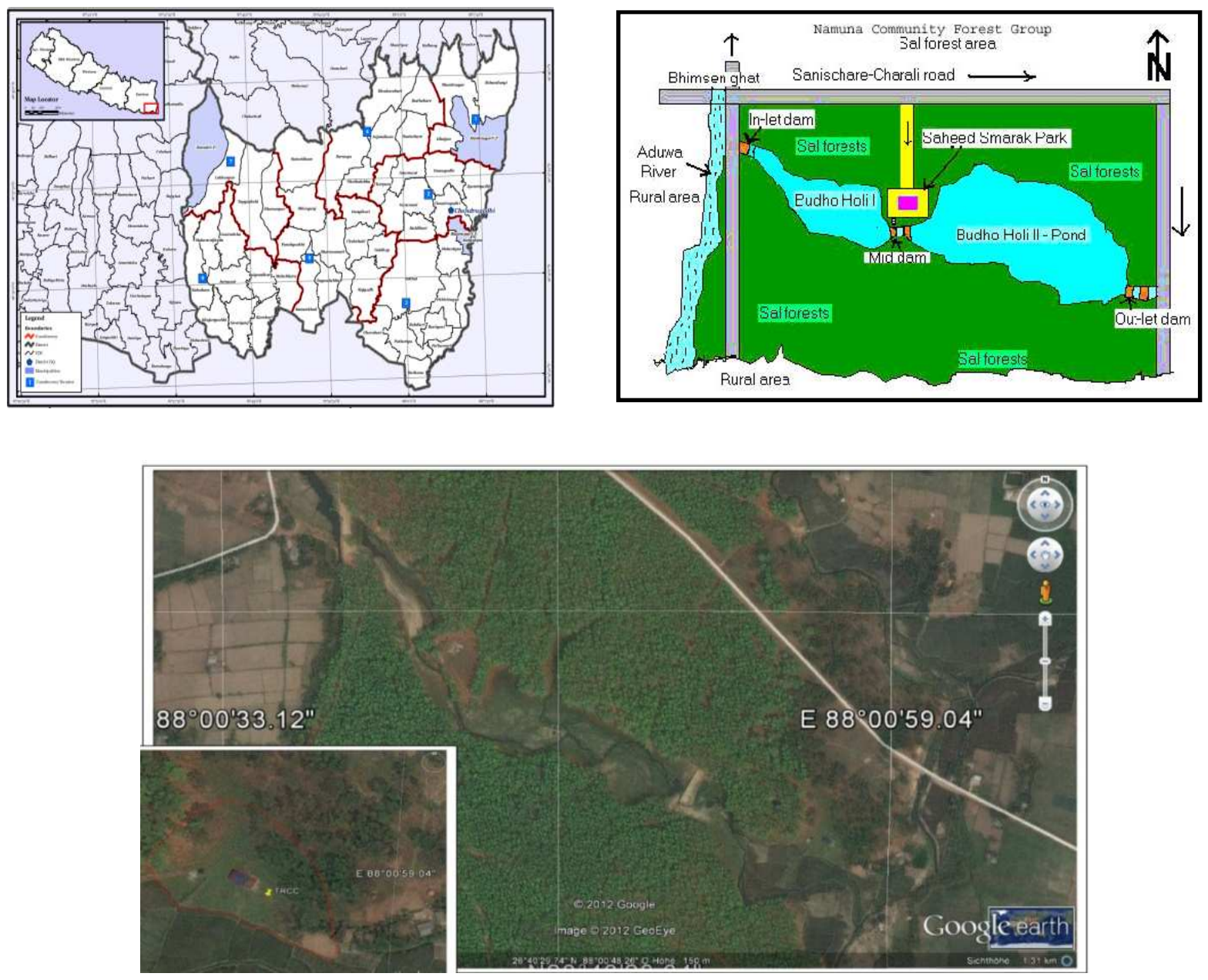

Figure 1: Location map of study area (TRCC), Jhapa, Nepal

to keep the records of rescued turtle scientifically, which are trans-located from various places to the centre; study the physico-chemical parameters of the Budhoholi lake and meteorological condition of study area. The study also helps to conclude whether the forest cum wetland site will be appropriate or not, for the development of Turtle rescue and conservation centre. The detailed study will help to protect turtles by identifying the root problem of their depletion and their rehabilitation. The centre will have multiple functions as a centre for education and research, conservation-tourism activities related to freshwater and terrestrial turtles. In the future, the centre will serve as "living" laboratories for freshwater and terrestrial turtle and encourage young scientist to conduct research regarding biology of freshwater and terrestrial turtles and threats to their survival in order to develop and implement innovative methods in the conservation of turtles.

\subsection{Need for the study}

Previous works revealed that the area was the suitable habitat for the various species of aquatic and terrestrial turtles. Records show that most of the endangered species of turtles are captured by local fisherman and sensorial collectors. The captured species were found either consumed as food or sell at local market for flesh and medicinal use [3]. Turtles have been used as food and in the preparation of traditional medicines since time immortal in Nepal [6]. Human impacts have affected the survival of turtles since prehistoric man has haunted them and gathered their eggs [4]. The burning poverty pressed the tribal ethnic group of Jhapa district such as Satar, Mushar to involve in catching to substitute their meal. The carapace and plastron was fed to the cattle after grinding [2]. All turtles in Nepal are threatened 
by international trade, local use, making tourist articles and killed as pests on fishery farms [6]. Such type of socio-ecological information is lacking in Nepal which has prompted to conduct the present study. Genera occurring east and west of Nepal like Geoclemys, Morenia, Hardella and the big growing species such as Kachugas cannot be found any more in wild [5]. The realization of TRCC will be dedicated to the restoration and rehabilitation of depleted wild populations of aquatic and terrestrial turtles in South-East Nepal. Therefore, a detailed scientific study on the socio-ecological impacts on the turtle felt urgently with appropriate management strategies for their conservation.

\section{Materials and methods}

The study is based on survey method. Samples of flora and fauna collected were identified with the help of field guide and pictorial literatures. The meteorological data were collected from Gainde irrigation project (meteorological centre), Maidhar. Interviews were conducted with local during field work to gather necessary information. The various turtles were rescued from different places. Turtles were transported by vehicle carefully by keeping inside wet cotton sac. Necessary biometry and GPS coordinates of the place of reception of specimen were recorded. Photographs were taken and the species were identified by the help of literatures and experts.

Table 1: Summary of some rescued turtle: $\mathrm{D}=$ Dorsum, $\mathrm{V}=$ Venter

\begin{tabular}{|c|c|c|c|c|c|c|}
\hline $\begin{array}{l}\mathbf{S} \\
\mathbf{N}\end{array}$ & Species & $\begin{array}{c}\text { Size } \\
(\mathbf{l - b}) \mathrm{cm}\end{array}$ & $\begin{array}{r}\text { Wt } \\
(\mathrm{gm})\end{array}$ & $\begin{array}{c}\text { Rescued } \\
\text { At }\end{array}$ & $\begin{array}{c}\text { GPS- } \\
\text { Coordinates }\end{array}$ & $\begin{array}{l}\text { Trans-ocated } \\
\text { @ TRCC on }\end{array}$ \\
\hline 1 & $\begin{array}{l}\text { Lissemys } \\
\text { punctata }\end{array}$ & $\begin{array}{l}\text { D } 9.5-9.0 \\
\text { V } 9.1-8.8\end{array}$ & 135 & $\begin{array}{l}\text { PG College, } \\
\text { Biratnagar }\end{array}$ & $\begin{array}{l}\text { N } 26^{\circ} 25^{\prime} 43^{\prime \prime} \\
\text { E } 87^{\circ} 16^{\prime} 8^{\prime \prime}\end{array}$ & $31 / 8 / 2012$ \\
\hline 2 & $\begin{array}{l}\text { Lissemys } \\
\text { punctata }\end{array}$ & $\begin{array}{l}\text { D } 8.0-7.5 \\
\text { V } 7.8-7.7\end{array}$ & 65 & $\begin{array}{l}\text { PG College, } \\
\text { Biratnagar }\end{array}$ & $\begin{array}{l}\mathrm{N} 26^{\circ} 25^{\prime} 43^{\prime \prime} \\
\text { E } 87^{\circ} 16^{\prime} 8^{\prime \prime}\end{array}$ & $31 / 8 / 2012$ \\
\hline 3 & $\begin{array}{l}\text { Lissemys } \\
\text { punctata }\end{array}$ & $\begin{array}{l}\text { D } 7.1-7.0 \\
\text { V } 7.0-6.8\end{array}$ & 45 & $\begin{array}{c}\text { PG College, } \\
\text { Biratnagar }\end{array}$ & $\begin{array}{l}\text { N } 26^{\circ} 25^{\prime} 43^{\prime \prime} \\
\text { E } 87^{\circ} 16^{\prime} 8^{\prime \prime}\end{array}$ & $31 / 8 / 2012$ \\
\hline 4 & $\begin{array}{c}\text { Nilssonia } \\
\text { hurum }\end{array}$ & $\begin{array}{ll}\text { D } & 47.0-37.0 \\
\text { V } & 42.2-37.5\end{array}$ & 9300 & $\begin{array}{c}\text { Dipeni River, } \\
\text { Damak }\end{array}$ & $\begin{array}{l}\text { N } 26^{\circ} 39^{\prime} 43^{\prime \prime} \\
\text { E } 87^{\circ} 41^{\prime} 36^{\prime \prime}\end{array}$ & $21 / 9 / 2012$ \\
\hline 5 & $\begin{array}{l}\text { Pangshura } \\
\text { flaviventer }\end{array}$ & $\begin{array}{ll}\text { D } & 16.0-12.0 \\
\text { V } & 15.0-11.5\end{array}$ & 520 & $\begin{array}{c}\text { Koshi Barrage, } \\
\text { Bhantabari }\end{array}$ & $\begin{array}{l}\text { N } 26^{\circ} 37^{\prime} 37^{\prime \prime} \\
\text { E } 87^{\circ} 01^{\prime} 55^{\prime \prime}\end{array}$ & $11 / 10 / 2012$ \\
\hline 7 & $\begin{array}{l}\text { Lissemys } \\
\text { punctata }\end{array}$ & $\begin{array}{ll}\text { D } & 10.5-9.5 \\
\text { V } & 10.0-8.5\end{array}$ & 180 & $\begin{array}{c}\text { Biratnagar-11, } \\
\text { Madhumara }\end{array}$ & $\begin{array}{l}\text { N } 26^{\circ} 27^{\prime} 55^{\prime \prime} \\
\text { E } 87^{\circ} 17^{\prime} 04^{\prime \prime}\end{array}$ & $30 / 11 / 2012$ \\
\hline 8 & $\begin{array}{c}\text { Indotestudo } \\
\text { elongata }\end{array}$ & $\begin{array}{ll}\text { D } & 20.5-4.0 \\
\text { V } & 15.0-2.0\end{array}$ & 1004 & $\begin{array}{c}\text { Bharatganj-6, } \\
\text { Bara }\end{array}$ & $\begin{array}{l}\text { N } 27^{\circ} 12^{\prime} 34^{\prime \prime} \\
\text { E } 85^{\circ} 13^{\prime} 20^{\prime \prime}\end{array}$ & $26 / 1 / 2013$ \\
\hline 9 & $\begin{array}{c}\text { Melanochelys } \\
\text { tricarinata }\end{array}$ & $\begin{array}{ll}\text { D } & 15.0-11 \\
\text { V } & 13.0-9.0\end{array}$ & 530 & $\begin{array}{c}\text { Bharatganj-6, } \\
\text { Bara }\end{array}$ & $\begin{array}{l}\text { N } 27^{\circ} 12^{\prime} 10^{\prime \prime} \\
\text { E } 85^{\circ} 13^{\prime} 25^{\prime \prime}\end{array}$ & $26 / 1 / 2013$ \\
\hline 10 & $\begin{array}{l}\text { Lissemys } \\
\text { punctata }\end{array}$ & $\begin{array}{l}\text { D } 10.5-10 \\
\text { V 10.0-8.5 }\end{array}$ & 140 & $\begin{array}{c}\text { Bargachhi } \\
\text { Biratnagar-4 }\end{array}$ & $\begin{array}{l}\text { N } 26^{\circ} 27^{\prime} 35^{\prime \prime} \\
\text { E } 87^{\circ} 17^{\prime} 15^{\prime \prime}\end{array}$ & $3 / 9 / 2013$ \\
\hline 11 & $\begin{array}{l}\text { Lissemys } \\
\text { punctata }\end{array}$ & $\begin{array}{l}\text { D } 13.5-13 \\
\text { V } 12.5-10\end{array}$ & 290 & $\begin{array}{c}\text { Bargachhi } \\
\text { Biratnagar-4 }\end{array}$ & $\begin{array}{l}\text { N } 26^{\circ} 27^{\prime} 35^{\prime \prime} \\
\text { E } 87^{\circ} 17^{\prime} 15^{\prime \prime}\end{array}$ & $3 / 9 / 2013$ \\
\hline
\end{tabular}




\section{Results and discussion}

Five species of turtles, of which three belongs to hard-shelled viz. Indotestudo elongata, Melanochelys tricarinata and Pangshura flaviventer while rest two species belong to soft-shelles viz. Lissemys punctata and Nilssonia hurum have been successfully rescued and translocated to the turtle rescue centre so far (Table 1). Of them, IUCN has listed Indotestudo elongata as endangered and Melanochelys tricarinata and Nilssonia hurum as vulnerable species (Table 2). Most of the rescue operations were conducted during August to November.

Table 2: Status of rescued turtles

Turtle Species

Hard-shelled

Indotestudo elongata

Melanochelys tricarinata

Pangshura flaviventer

Soft-shelled

Lissemys punctata

Nilssonia hurum
Recorded No.

\% Cover

IUCN

CITES

Endangered

Vulnerable

Near threatened

9

1

9

7

1
Lower Risk

Vulnerable
II

I

II

II

I
ARCO

Vulnerable

Endangered

Least concern

Leastconcern

Endangered

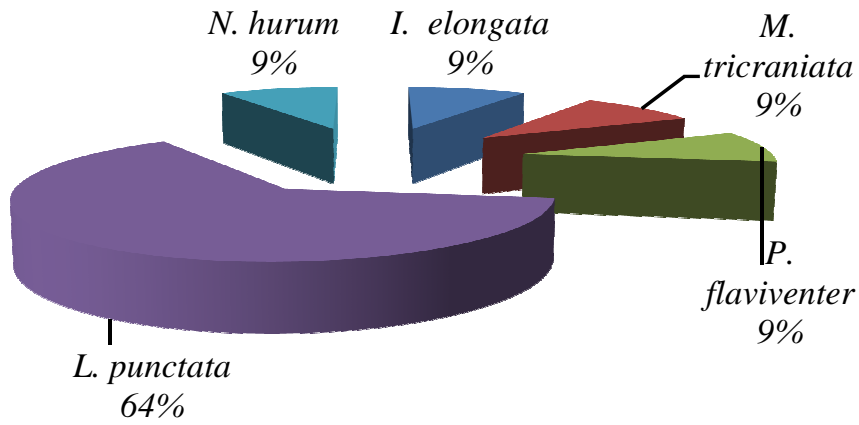

Figure 2: Pie-chart showing percentages cover of turtles (Species wise).

Table 3: Month-wise records of rescued species (2013).

\begin{tabular}{|c|c|c|c|c|c|c|c|c|c|c|c|c|}
\hline Species & Jan & Feb & Mar & Apr & May & Jun & Jul & Aug & Sep & Oct & Nov & Dec \\
\hline I. elongata & + & - & - & - & - & - & - & - & - & - & - & - \\
\hline M. tricarinata & + & - & - & - & - & - & - & - & - & - & - & - \\
\hline P. flaviventer & - & - & - & - & - & - & - & - & - & + & - & - \\
\hline L. punctata & - & - & - & - & - & - & - & + & + & - & + & - \\
\hline N. hurum & - & - & - & - & - & - & - & - & + & - & - & - \\
\hline
\end{tabular}




\subsection{Description and locality records of some of rescued species}

\section{Indotestudo elongata (Blyth 1853)}

Lat. Testudo or testa: brick, earthen pot; elongates: elongated

$\begin{array}{ll}\text { Status: } & \text { IUCN: Endangered, CITES: II, ARCO: Vulnerable (hunted for masks) } \\ \text { Etymology: } & \text { E. Yellow-headed tortoise; N. Bhuin /Sun Kachhuwa } \\ \text { Biometry: } & (1 \times b) \mathrm{cm} \text { : Carapace } 20.0 \times 8.0 ; \text { Plastron: } 15.0 \times 6.0 \\ \text { Weight: } & 1.4 \mathrm{~kg} \\ \text { Location: } & \text { Bharatganj, Bara } \\ \text { GPS coordinates: } & \text { N } 27^{\circ} 12^{\prime} 34^{\prime \prime} / \mathrm{E} 85^{\circ} 13{ }^{\prime} 20^{\prime \prime} \\ \text { Rescued on: } & 26 / 1 / 2013 ; 1750 \text { hrs (crawling to bank of Dipeni river; caught by hand) } \\ \text { Resource person: } & \text { Om BK, Local person } \\ \text { Identification key: } & \text { Upper jaw tricuspid with pointed tip which is bent downwards } \\ \text { Limbs: } & \text { Greenish grey to dark grey, with yellow scales; claws yellow to whitish } \\ \text { Carapace: } & \text { Carapace yellow to grayish or greenish yellow, even reddish brown } \\ \text { Plastron: } & \text { Large, truncate anteriorly, notched posteriorly } \\ \text { Egg size: } & 3 \times 5 \mathrm{~cm} \\ \text { Incubation period: } & 135 \text { days }\end{array}$

3.1.1. Melanochelys tricarinata (Blyth, 1853)

Gr. melas: black; chelys: turtle; tria: three; carina:keel

Status: $\quad$ IUCN: Vulnerable, CITES: I, ARCO: Endangered

Etymology: $\quad$ E. Three-keeled land tortoise; N. Tin-pate Pahadi Kachhuwa/ Thotari

Biometry: $\quad(1 \times b) \mathrm{cm}$ : Carapace $15.0 \times 11.0 ;$ Plastron: $13.0 \times 9.0$

Weight: $\quad 530 \mathrm{gm}$

Location: Bharatganj-6, Bara

GPS coordinates: $\quad$ N $27^{\circ} 12^{\prime} 34^{\prime \prime}$; E $85^{\circ} 13^{\prime} 20^{\prime \prime}$

Rescued on: $\quad 20 / 01 / 2013 ; 1830 \mathrm{hrs}$ (caught by hand while hiding beneath wooden $\log$ )

Resource person: $\quad$ Om B.K., Bara

Identification key: Three narrow keels, prominent due to their yellow coloration

Coloration: $\quad$ Light brown, with yellowish to light brown keels and margin;

Carapace: $\quad$ Convex with three prominent keels runs parallel to each other

Plastron: $\quad$ Light yellow to orange, formula: abd $>$ pect $>$ an $>$ gul $>$ fem $>$ hum.

Head: $\quad$ Posterior part of the upper head is divided in to large shields

Forelimbs: $\quad$ With elongated or pointed scales, fingers are half webbed; Tail short

Sexual dimorphism: Male with concave plastron, large hind limbs, longer / thicker tail

Diet: Crepuscular and omnivorous.

Nesting: $\quad$ Clutch size 1-3 eggs. Produce Feb/Apr,Oct/Dec hatches after 60-72 days.

\subsubsection{Pangshura flaviventer (Gunther,1864)}

Bengal.pangshura: turtle; Lat.flavus: yellow; venter: belly

Status:

Etymology:

Biometry:

Weight:

Location:

GPS coordinates:

Rescued on:

Resource person:

Identification key:
IUCN: Near threatened, CITES: II, ARCO: Least concern

E. Yellow-bellied roofed; N. Pahelo bhunde dhuri Kachhuwa

$(\mathrm{l} \times \mathrm{b}) \mathrm{cm}$ : Carapace $16.0 \times 12.0$; Plastron: $15.0 \times 11.5$

$520 \mathrm{gm}$

Koshi Barrage

$\mathrm{N} 26^{\circ} 37^{\prime} 37^{\prime \prime}$; E $87^{\circ} 01^{\prime} 55^{\prime \prime}$

$11 / 10 / 2012 ; 1400 \mathrm{hrs}$ (trapped by fisherman and kept for sell)

Prem Narayan Yadav

$3^{\text {rd }}$ vertebral plate carries a sharp projection. 
M. Kharel \& D. Thapa Chhetry / BIBECHANA 11(1) (2014) 141-148 (Online Publication: March, 2014) p.146

Coloration: $\quad$ Carapace brownish; Posterior head pale pink

Head: Grey pigmentation is present around the eyes

Category: $\quad$ IUCN: listed as synonym to $P$. tentoria;

CITES: listed as synonym to $P$. tecta

ARCO-Nepal listed as $P$. flaviventer as an independent own species

3.1.3. Lissemys punctata (Bonnaterre, 1789)

Gr.lissa: rage; Lat. punctatus: dotted

Status: $\quad$ IUCN: Lower Risk, CITES: II, ARCO: Least concern

Etymology: $\quad$ E. Indian Flapshell turtle; N. Dhakani khabate/ Putali Kachhuwa

Biometry: $\quad(1 \times b) \mathrm{cm}$ : Carapace $13.5 \times 13.0 ;$ Plastron: $12.5 \times 10.0$

Weight: 290 gm

Location: Bargachhi, Biratnagar

GPS coordinates: $\quad$ N 26 $26^{\circ} 35^{\prime \prime}$; E 87 $87^{\circ} 17^{\prime} 15^{\prime \prime}$

Rescued on: $\quad 03 / 09 / 2013 ; 0900 \mathrm{hrs}$ (trapped by lab boy and kept in aquarium)

Resource person: Dhan Bahadur

Identification key: Carapace dotted with yellow. Semicircular flaps on plastron

Coloration: Olive green to dark brown with yellow dots; plastron white

Sexual dimorphism: Tail comparatively longer with thicker base in male

Nesting:

Eggs:

Clutch size:

Diet:

Between end of August and mid September in sandy or sand loam soil.

Brittle-shelled, spherical, 24-30 $\mathrm{mm}$ in diameter

2-14 eggs; incubation period 241-412 days

Omnivorous, voracious, scavenger on animal corpses far from water

bodies also takes tadpoles, fish, invertebrates and aquqtic plants.

Forelimbs: $\quad$ With 5 claws; hind limbs with 4 claws; tail ending in a horny nail.

Coloration: $\quad$ Carapace olive green to dark brown with irregular yellow dots with a dark edge plastron white; head yellowish; limb greenish grey to dark grey.

\subsubsection{Nilssonia hurum (Gray 1832)}

Gr.aspis: shield; eretes: oarsman, rower

Status:

Etymology:

Biometry:

Weight:

Sex:

Location:

GPS coordinates:

Rescued on:

Resource person:

Identification key:

Coloration:

Carapace:

Plastron:

Nesting:

Egg:

Sexual dimorphism:
IUCN: Vulnerable, CITES: I, ARCO: Endangered

E. Indian Peacock soft-shell turtle ; N. Mayurpankhi/ Chartari Kachhuwa (l×b) cm: Carapace $47.0 \times 37.0$; Plastron: $42.2 \times 37.5$

$9.3 \mathrm{~kg}$;

Male

Dipeni River, Damak, Jhapa

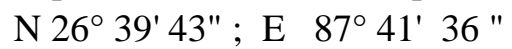

21/09/2012; 1750 hrs (crawling to bank of Dipeni river; caught by hand)

Reported by M. Kharel for the first time from Jhapa district

Large aquatic turtle with a snout; juveniles have 4-6 distinct eyes spots on carapace

Head with dark green or black lines, with yellow spots.

Olive green with black reticulation, normally with 4 spots

(5/6 occasionally)

Brownish grey, pales with age.

August-December in clay-sandy soil.

Spherical, hard- shelled, about $30 \mathrm{~mm}$ in diameter, 20-30 eggs per clutch

Male poses comparatively longer and thicker tails than female 


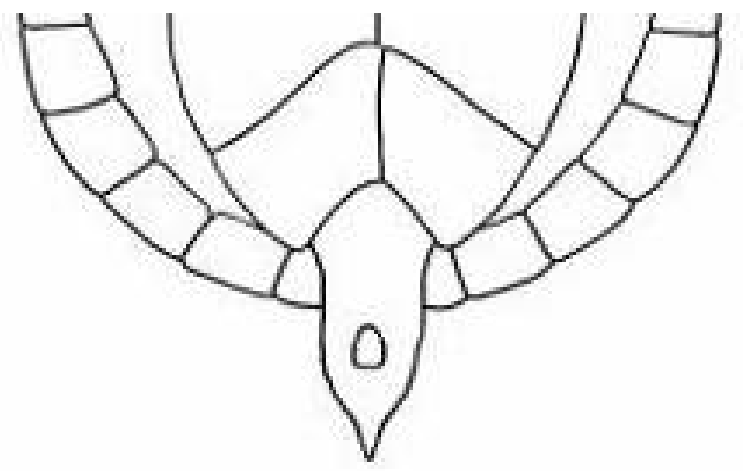

Male

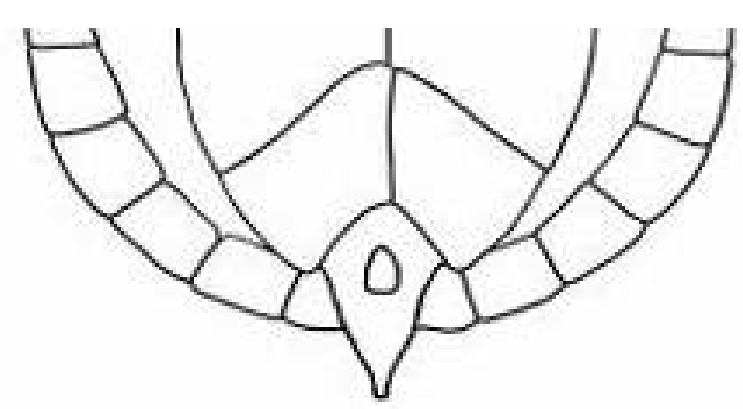

Female

\subsection{Meteorological data}

During study some of the climatic parameters such as dissolved oxygen of main lake, temperature of water and average rainfall records, it was found that he following climatic factors of the study area were favorable to support their growth and conservation.

Average DO:

Ave. water temp:

Ave. Rainfall:
$7.4^{*}( \pm 0.301) \mathrm{mg} / \mathrm{l}($ Max. Jan $)$

$21^{*}( \pm 0.283)^{\circ} \mathrm{C}$

$6.25 * \mathrm{~mm}$ (Max:25mm)

* Considered sufficient enough to support aquatic life

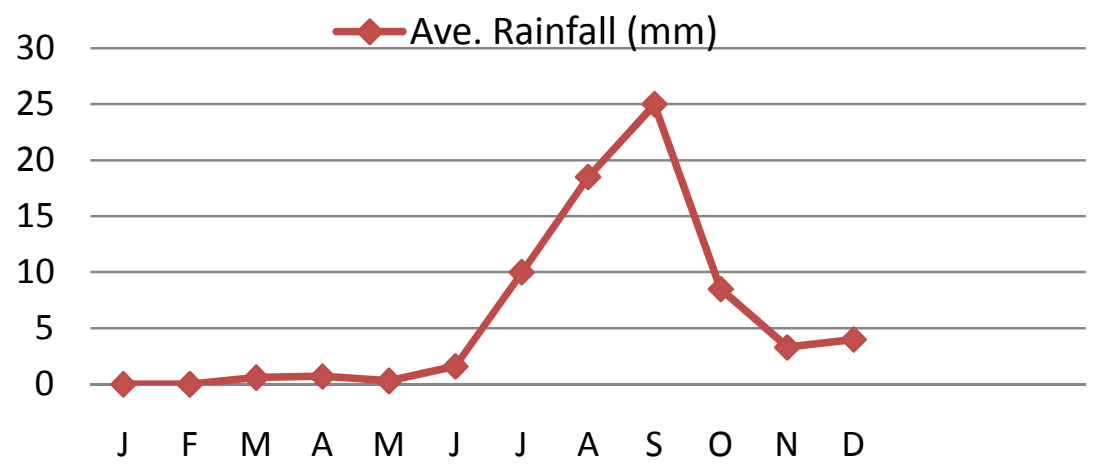

Figure 3: Average rainfall recorded in the study area (2013).

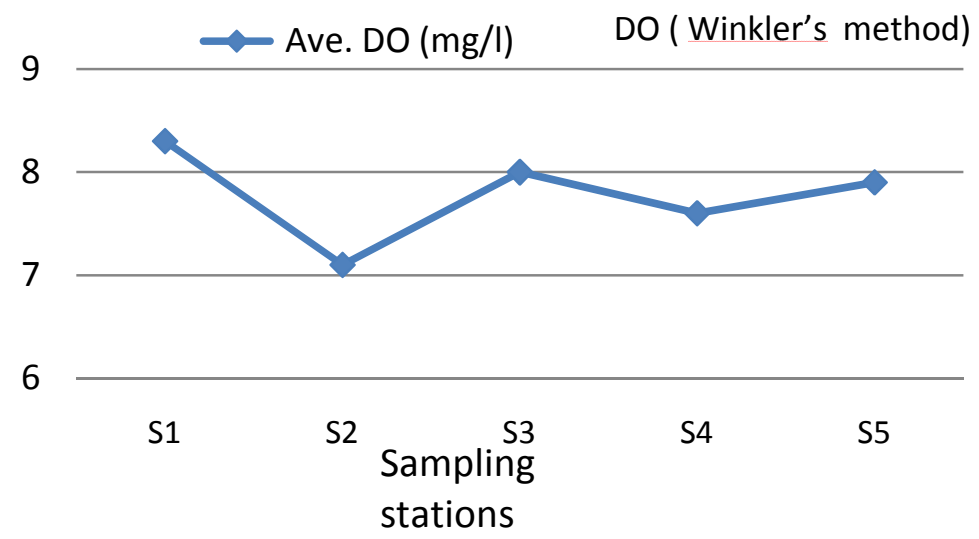

Figure 4: Average dissolved oxygen in study area. 


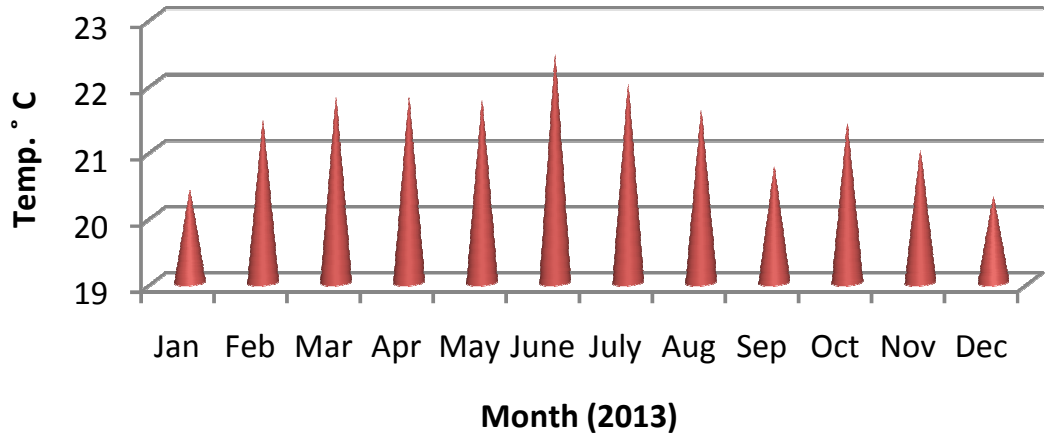

Figure 5: Average water temperature of study area (month wise).

\section{Conclusion}

Climatic data shows the average annual temperature and average rainfall pattern of Jhapa district is suitable to support the flora and fauna of tropical climatic zone. It could be one of the hotspot for the conservation of turtles. During, preliminary study, five species of turtles have been rescued and translocated in the TRCC. A male of Nilssonia hurum $(9.3 \mathrm{~kg}$ ) reported for the first time from Jhapa district. During field visit, two species Pangshura flaviventer (as pet and ornament) and Lissemys punctata (for food and traditional medicine) were found overexploited by local fisherman specially from Koshi barrage area. However, the population growth rate is quite high and habitats of wildlife have been decreasing day by day. It indicated the urgent need of protection of turtle and other endangered flora and fauna in the study area.

Largest rescued species:

Frequently rescued species:

Rare rescued species:

Popular pet trade species: Most easily captured species: Popular area for turtle trade:

\author{
Nilssonia hurum $(9.3 \mathrm{~kg})$ \\ Lissemys punctata $(64 \%)$ \\ Melanochelys tricarinata \\ Pangshura flaviventer \\ Indotestudo elongata
}

Koshi Barrage area

\section{Acknowledgments}

Thanks are due to Prof. Dr. Kalu Ram Rai 'Khambu', HOD (Department of Zoology), Mechi Multiple Campus, Bhadrapur, (T.U.), Nepal for giving us continuous guidance, inspiration, personal assistance during field trip and supply of useful literatures. We are grateful to the Sukhani Martyr's Memorial Foundation (SUMMEF) for granting my research in the premises of the park area. The first author is grateful to founder of ARCO-Nepal, Prof. Dr. H. Hermann Schleich, University of Munich (Germany) for providing financial assistance to conduct this study.

\section{References}

[1] DDC, District Profile, District Development Committee, Jhapa, 2002.

[2] M. Kharel, General Survey of Anthropogenic Impacts on Chelonian Fauna in the Kankai (Mai) river and its vicinities, Jhapa, East Nepal, M. Sc. Thesis submitted to Department of Zoology, Post-Graduate Campus, T.U., Biratnagar, 2011.

[3] K.R. Rai, Environmental Impact Systematics and Distribution of Herpetofauna from East Nepal, Ph.D. Thesis submitted to the Central Department of Zoology, T.U., Kritipur, Kathmandu, 2003.

[4] H.H. Schleich, The Turtles of Nepal, A Children Coloring Book, Pub. ARCO Nepal Reg. Soc. Fuhlrott-Museum, 2004.

[5] H.H Schleich, K. Ernst, T.M. Maskey, Urgent Call for Turtle Conservation in Nepal, In Nepal Myths and Realities (Ed. R.B. Thapa \& J. Baaden), 1998.

[6] K.B. Shah, J. Nat. Hist. Mus. 13 (2004) 19. 